\title{
Study of Physicochemical and Bacteriological Quality of Treated Wastewater by the New Aourir Plant (Southwestern of Morocco) Using Activated Sludge Technology in a Semi-Arid Region
}

\author{
Sara Hajji ${ }^{*}$, Aicha Ait Alla', Slimani Noureddine', \\ Mohamed Ben Haddad', Abdellatif Moukrim² \\ 1 Laboratory of Aquatic Systems: Marine and continental ecosystems, Faculty of Sciences, Ibn Zohr University, \\ Agadir, Morocco \\ 2 Faculty of Sciences, Abdelamalek Essadi University, Tetouan, Morocco \\ * Corresponding author's email: Sarahajji5@gmail.com
}

\begin{abstract}
In order to use the purified wastewater for the irrigation of a golf course in the Taghazout area (Southwestern of Morocco), this study was conducted to evaluate the physicochemical and bacteriological quality of the treated wastewater in the new Aourir plant (Activated Sludge technology). In order to achieve these objectives, three types of water were analyzed: raw water (RW), biologically treated water (BTW) and water treated by ultraviolet radiation (UV-TW). The physicochemical parameters analyzed were Temperature, $\mathrm{pH}$, Electrical Conductivity (EC), Dissolved Oxygen (DO), Chemical Oxygen Demand (COD), five-day Biological Oxygen Demand $\left(\mathrm{BOD}_{5}\right.$ ), Total Suspended Solids ( $\mathrm{SS})$, Nitrate $\left(\mathrm{NO}_{3}\right)$, and Orthophosphates $\left(\mathrm{PO}_{4}\right)$. Otherwise, the analyzed biological parameters are Total Coliforms (TC), Fecal Coliforms (FC), Escherichia coli (E. coli), and Fecal Streptococci (FS). The physicochemical parameters showed that temperature is always lower than $30^{\circ} \mathrm{C}$, the $\mathrm{pH}$ is close to neutrality and a strong fluctuation of the high electrical conductivity $(2700 \mu \mathrm{S} / \mathrm{cm})$ occurs in UV-TW. At all stages of wastewater treatment, $\mathrm{COD}, \mathrm{BOD}_{5}, \mathrm{SS}, \mathrm{NO}_{3}$ and $\mathrm{PO}_{4}$ were below the limit values recommended by Moroccan standards. The bacteriological results showed a high level of bacterial contamination in RW and BTW, but in UV-TW the loads did not exceed $3 \log 10$. The average loads of TC, FC, E. coli and FC in UV-TW were 2.13, 1.67, 1.77, and $2(\log 10$ $\mathrm{CFU} / 100 \mathrm{ml}$ ) respectively. Activated sludge treatment combined with UV has demonstrated sufficient quality to reuse treated water in irrigation; however, the UV treatment requires control to avoid any effect on the microbiological and physicochemical quality of green spaces and groundwater.
\end{abstract}

Keywords: wastewater, Morocco, physicochemical parameters, activated sludge, Aourir, bacteriological parameters, treatment plants

\section{INTRODUCTION}

Following the development and growth of urban, agricultural and industrial activities in Morocco, the production of wastewater has become very important. This causes a great health and environmental risk. Therefore, the treatment of wastewater becomes a necessity for environment protection (Hachemi et al., 2012). The purpose of wastewater treatment is either to discharge into the natural environment or to reuse the water that must meet standards set by the authorities responsible for water resources management. According to Haité (2010), the volume of wastewater in Morocco is estimated at 900 million $\mathrm{m}^{3}$ / year in 2020. The pollutant load of wastewater is estimated at around 131715 tons of organic load, 42131 tons of nitrogen and 6230 tons of phosphorus (Mandi et al., 2013). Morocco, like most of the southern Mediterranean countries, suffers from the scarcity of conventional water resources, which constitutes a social, agricultural, and economic problem. The water problem in these countries is the result of a combination of arid climatic 
conditions as well as an increase in water needs due to population growth and the development of tourism. It is, therefore, necessary to provide alternative water sources for agriculture to replace the high quality water required for consumption (Angelakis et al., 1999). In this context, the reuse of treated wastewater seems to be a good alternative especially in irrigation. This resource is abundantly and permanently available. It has many advantages, notably reasonable cost compared to desalinating seawater or digging wells. It ensures the balance of the natural water cycle and protection of the environment, as has been proven in many countries of the Mediterranean region, such as Israel, Cyprus, Jordan and Tunisia (Angelakis et al., 1999). Despite the benefits of wastewater reuse, it could present significant risks for users and the environment (Habbari et al., 2000; Cha et al., 2004; Qadir et al., 2010; Fatta-Kassinos et al., 2011). Multiple studies have proven that microbial contamination represents a real risk. A large variety of pathogenic microorganisms has been isolated from wastewater (Vaz-Moreira et al., 2014). Chemical contaminants pose serious risks to health and the environment; wastewater can contain pesticides, pharmaceuticals and heavy metals (Tarchouna et al., 2010; Köck-Schulmeyer et al., 2013). Currently, Morocco has more than 100 wastewater treatment plants which are part of pollution control strategy, reuse of treated wastewater, and contribution to sustainable development (Tahri et al., 2015). In this context, The Anza-Taghazout sector in the Agadir region (southwestern of Morocco) is among the sectors benefiting from the new treatment plants: lamellar settling in Anza and activated sludge in Aourir. The setting up of wastewater treatment plants in this sector is a major step towards modifying the sanitary quality of the marine ecosystem in this area. The new station of Aourir using activated sludge technology is the first in its kind in the Agadir region, characterized by its semi-arid climate. This very low charge station located between Tamraght and Aourir will serve more than 61,000 citizens. The purpose of this study was to evaluate the possibility of reusing the treated wastewater from the Aourir treatment plant in the irrigation of green spaces. It mainly consists in estimating the overall organic pollution and the sanitary quality of the effluents. In order to ensure the proper adaptation of this treatment system with the semi-arid climate of the region, it is necessary, first of all, to identify the sources of pollution at the entrance of this station, and then to evaluate its purification performance. The results will be confronted with the Moroccan and European standards.

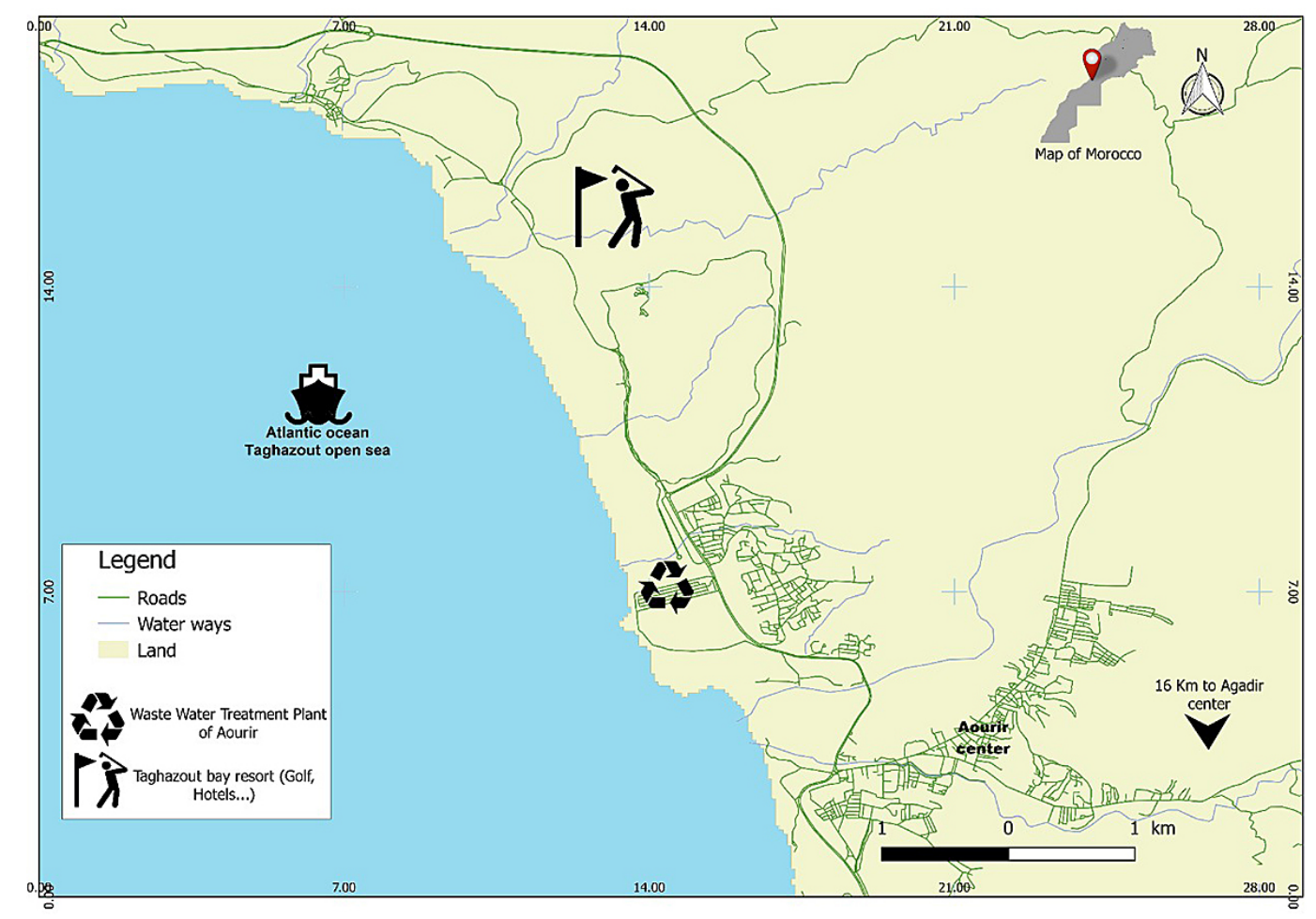

Figure 1. Geographical location of Aourir wastewater treatment plant 


\section{MATERIAL AND METHODS}

\section{Geographical location of the study site}

The Aourir treatment plant $\left(30^{\circ} 32^{\prime} 44.189^{\prime \prime} \mathrm{N}\right.$, $\left.9^{\circ} 42^{\prime} 29.297^{\prime \prime} \mathrm{W}\right)$ is located near the ocean, northwest of Aourir and about $700 \mathrm{~m}$ south of the Taghazout bay tourist resort located $12 \mathrm{~km}$ from the Agadir city and $8 \mathrm{~km}$ from Taghazout. The Aourir treatment plant covers an area of 2.5 hectares $(200 \times 125 \mathrm{~m})$. Figure 1 shows the location of this treatment plant.

\section{Description of Aourir treatment plant}

The effluent treatment channels includes a water treatment system with pretreatments, biological treatment and tertiary treatment, as well as a sludge treatment and a stale air treatment (deodorization) line (Figure 2). Conventional pretreatment consists in a succession of screening, grit removal and de-oiling, followed by a combined treatment between the biological system (Table 1), which consists in passing the treated wastewater into two aeration tanks for biological degradation of the organic matter by biomass, followed by a mechanical system which consists in decanting all the sludge in the clarification tanks. The biological treatment is the activated sludge type with a very low load. Tertiary finalization treatment consists in series of mechanical filtration operations $(10-\mu \mathrm{m}$ microfiltration) and UV disinfection (Table 1). The total flow of treated wastewater would be around $7600 \mathrm{~m}^{3} / \mathrm{d}$ for 60833 population equivalent at the project saturation horizon (2030), which corresponds to

Table 1. Sizing of structures and description of equipment of the wastewater treatment process of the Aourir plant

\begin{tabular}{|c|c|c|}
\hline Treatment Stages & \multicolumn{2}{|c|}{ Characteristics } \\
\hline \multirow{10}{*}{ Biological Basin } & \multicolumn{2}{|c|}{ Contact Area } \\
\hline & Number of basins & 2 \\
\hline & Maximum flow rate per basin & $840 \mathrm{~m}^{3} / \mathrm{h}$ \\
\hline & Unit volume of the contact area & $145 \mathrm{~m}^{3}$ \\
\hline & Length of stay & $10 \mathrm{~min}$ \\
\hline & \multicolumn{2}{|c|}{ Air Zone } \\
\hline & Number of basins & 2 \\
\hline & Unit volume of basins & $5974 \mathrm{~m}^{3}$ \\
\hline & Global sludge age & $21 \mathrm{j}$ \\
\hline & Length of stay & $38,5 \mathrm{~h}$ \\
\hline \multirow{5}{*}{ Clarification Basin } & Number of basins & 2 \\
\hline & Maximum flow rate & $840 \mathrm{~m}^{3} / \mathrm{h}$ \\
\hline & Maximum flow rate per basin & $462.5 \mathrm{~m}^{3} / \mathrm{h}$ \\
\hline & Total diameter of the basin & $32,4 \mathrm{~m}$ \\
\hline & Height in water of the cylindrical part & $3,5 \mathrm{~m}$ \\
\hline \multirow{7}{*}{ Tertiary Filtration } & $\begin{array}{c}\text { Type } \\
\end{array}$ & Mechanical filtration on canvas \\
\hline & Cut-off threshold & $10 \mu \mathrm{m}$ \\
\hline & Number of filters & 2 \\
\hline & Maximum flow rate & $840 \mathrm{~m}^{3} / \mathrm{h}$ \\
\hline & Maximum flow rate per filter & $420 \mathrm{~m}^{3} / \mathrm{h}$ \\
\hline & Unit filtering surface & $45 \mathrm{~m}^{2}$ \\
\hline & Filtration speed & $9,3 \mathrm{~m} / \mathrm{h}$ \\
\hline \multirow{8}{*}{ UV Disinfection } & Type & lampes UV-C basse pression \\
\hline & Number of reactors & 3 \\
\hline & Maximum flow rate & $840 \mathrm{~m}^{3} / \mathrm{h}$ \\
\hline & Maximum flow rate per reactor & $280 \mathrm{~m}^{3} / \mathrm{h}$ \\
\hline & UV transmittance & $65 \%$ \\
\hline & Wavelength & $254 \mathrm{~nm}$ \\
\hline & Exposure dose & $65,2 \mathrm{~mJ} / \mathrm{cm}^{2}$ \\
\hline & Power per reactor & $12 \mathrm{~kW}$ \\
\hline
\end{tabular}




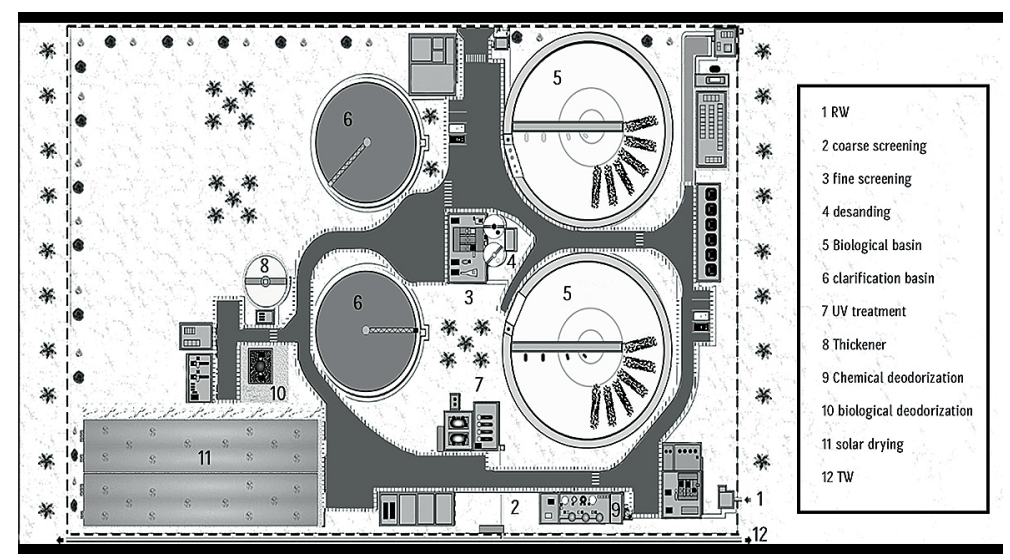

Figure 2. Synoptic diagram of the Aourir wastewater treatment plant

a peak hour flow of $840 \mathrm{~m}^{3} / \mathrm{h}$. The current flow rate that the subjected to treatment in the plant is approximately $1600 \mathrm{~m}^{3} / \mathrm{d}$.

\section{Samples collection}

A total of 63 samples were collected over 21 months; from April 2017 to December 2018. Monthly, three samples were collected (Figure 1). It included: raw water (RW) at entrance to the plant, biological treated water (BTW), and finally, treated water disinfected with ultraviolet radiation (UV-TW) at the exit of the UV reactors.

\section{Studied parameters}

The overall physicochemical parameters $\left(\mathrm{T}^{\circ}\right.$, $\mathrm{pH}$, dissolved $\mathrm{O}_{2}$ and conductivity) were measured in situ using a "Conductivity Meter" and "pH-meter" by the THERMO Scientific electrode, and the BANTE electrode instrument for the measurement of dissolved oxygen. $\mathrm{BOD}_{5}$, COD, SS were measured on monthly composite samples (RW, BTW, UV-TW). For suspended solids (SS), the measurement method adopted was differential weighing by filtration on GFC filter and drying at $105^{\circ} \mathrm{C}$ (AFNOR, T90-105). The five-day biological oxygen demand $\left(\mathrm{BOD}_{5}\right)$ was determined by using the manometric method with a respirometer (types WTW), according to the AFNOR standard (AFNOR, T90-103). The chemical oxygen demand (COD) was determined with the oxidizability with potassium dichromate (AFNOR, T90-101). The determination of nitrates $\left(\mathrm{NO}^{3}\right)$ was performed with the method based on sodium salicylate (AFNOR T90-013). Orthophosphates $\left(\mathrm{PO}_{4}^{3-}\right)$ were determined by colorimetric measurement of the phosphomolybdic complex formed (AFNOR T90-023). The bacteriological analyses of the wastewater samples consisted in enumerating the germs indicative of fecal contamination, i.e. total coliforms (TC), fecal coliforms (FC), Escherichia coli (E. coli) and fecal streptococci (FS). The enumeration methods depend on the origin, nature and quality of the sample. In the conducted study, the bacterial enumeration was performed by the technique of dilution and spreading of $0.1 \mathrm{~mL}$ of the diluted sample on the agar specific to the microorganisms sought on the raw wastewater. The treated water was analyzed with the membrane filtration technique (100 mL on $0.45 \mu \mathrm{m}$ membrane). Incubation on TTC-Tergitol-Agar for $24 \mathrm{~h}$ at $44^{\circ} \mathrm{C}$ for fecal coliforms (ISO 9308-1, 2000), and 24 to $37^{\circ} \mathrm{C}$ for total coliforms. Bile tryptone agar with X-glucuronide (TBX agar) for $24 \mathrm{~h}$ at $44^{\circ} \mathrm{C}$ for E.coli (ISO 9308-1, 2000). Slanetz-Bartley agar at $37^{\circ} \mathrm{C}$ for $48 \mathrm{~h}$ for fecal streptococci (ISO 7899-2, 2004).

\section{Statistical analysis}

The relationship between the microbiological and physicochemical parameters was analyzed using the Pearson Correlation Test. The analysis of variance (ANOVA) was performed in order to compare the changes in the water quality at the inlet and outlet of the treatment plant, caused by the treatment system. The ANOVA test was used to compare the concentrations of each parameter between seasons, years and between treatment steps using SPSS statistics24 with a significance level of 0.05 and 0.01 . 
(a)

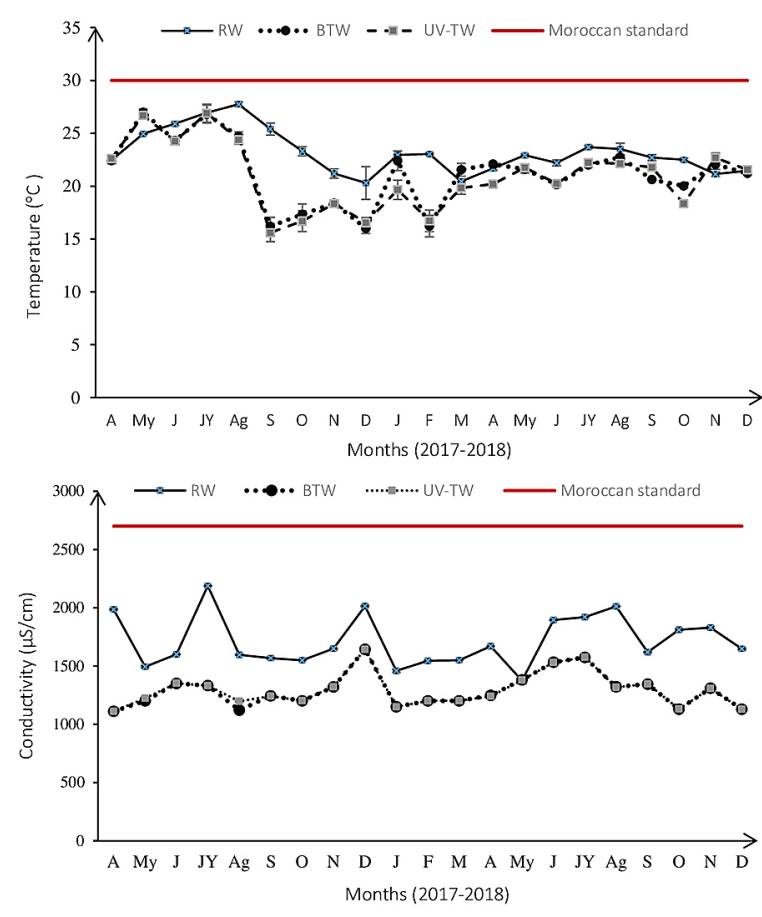

(c) (b)
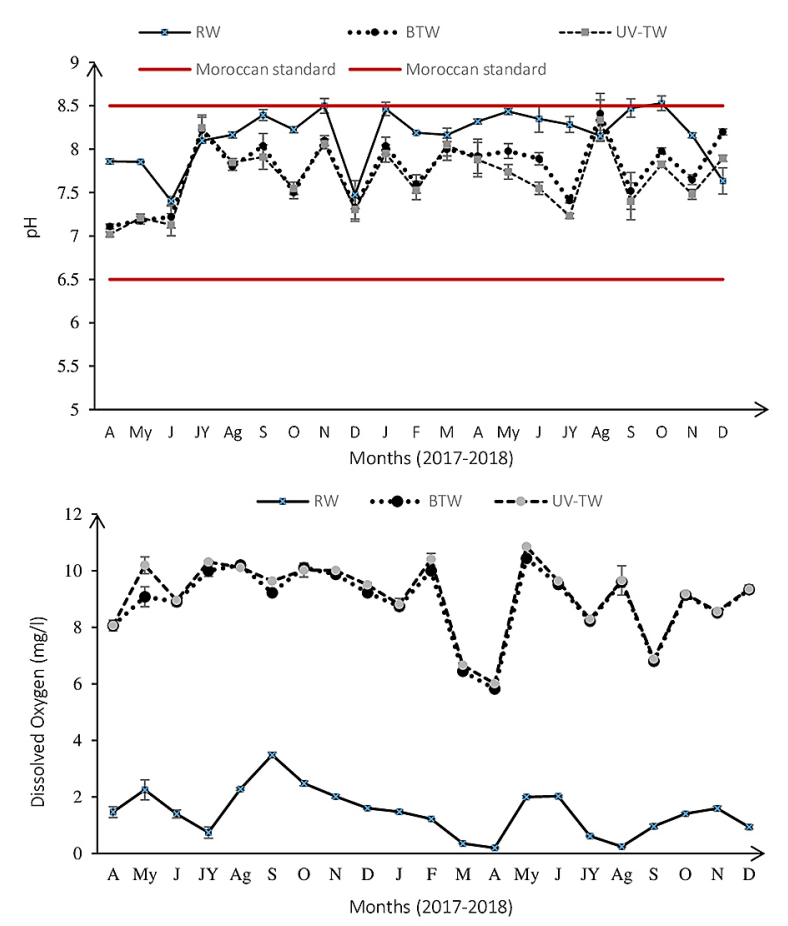

(d)

Figure 3. Monthly variation of physicochemical parameters during the sampling period.

a) temperature, b) $\mathrm{pH}, \mathrm{c}$ ) conductivity, d) dissolved oxygen

\section{RESULTS}

\section{Physicochemical parameters}

The monthly wastewater temperature is shown in Figure 3a. The RW temperature ranges from $20.3 \pm 1.55^{\circ} \mathrm{C}$ to $27.75 \pm 0.21^{\circ} \mathrm{C}$, with an average of $23.20 \pm 0.27^{\circ} \mathrm{C}$. For BTW, it varies between $16 \pm 0.33^{\circ} \mathrm{C}$ and $27 \pm 0.20^{\circ} \mathrm{C}$ with an average of $21.17 \pm 0.33^{\circ} \mathrm{C}$. The temperature of UV-TW, it is between $15.6 \pm 0.84^{\circ} \mathrm{C}$ and $26.9 \pm 0.84^{\circ} \mathrm{C}$ with an average of $20.9 \pm 0.42^{\circ} \mathrm{C}$. During the sampling period, the $\mathrm{pH}$ values ranged from $7.40 \pm 0.04$ to $8.53 \pm 0.08$ and $7.02 \pm 0.02$ to $8.33 \pm 0.23$ for RW and UV-TW, respectively (Figure $3 b$ ). The average $\mathrm{pH}$ value of $\mathrm{RW}$ is about $8.14 \pm 0.06$ indicating low alkalinity of wastewater, $7.76 \pm 0.08$ of BTW; however, the annual average of UV-TW remains close to neutral $7.67 \pm 0.09$. The average values of Electrical Conductivity in RW, BTW and UV-TW are $1712.76 \pm 5.11,1287 \pm 5.44$ and $1291.97 \pm 8.38(\mu \mathrm{S} / \mathrm{cm})$, respectively; it varies between $1374 \pm 3.53$ and $2188 \pm 2.82$ in RW ; $1110 \pm 2.10$ and $1644 \pm 1.22$ in BTW ; $1111.5 \pm 12.0$ and $1643 \pm 1.41(\mu \mathrm{S} / \mathrm{cm}$ ) in UV-TW (Figure 3c).
The concentration of dissolved oxygen in RW varies between $0.22 \pm 0.02 \mathrm{mgO}_{2} / \mathrm{L}$ and $3.48 \pm 0.09$ $\mathrm{mgO}_{2} / \mathrm{L}$ with an average value of $1.46 \pm 0.08$ $\mathrm{mgO}_{2} / \mathrm{L}$. The average concentration of dissolved oxygen in $\mathrm{BTW}$ is $8.91 \pm 0.04 \mathrm{mgO}_{2} / \mathrm{L}$, the minimum value is $5.82 \pm 0.04 \mathrm{mgO}_{2} / \mathrm{L}$ and the maximum is $10.44 \pm 0.12 \mathrm{mg} \mathrm{O}_{2} / \mathrm{L}$. For UV-TW, the dissolved oxygen content varies between $6.01 \pm 0.06 \quad \mathrm{mgO}_{2} / \mathrm{L}$ and $10.85 \pm 0.12 \quad \mathrm{mgO}_{2} / \mathrm{L}$, with an average value of $9.09 \pm 0.04 \mathrm{mgO}_{2} / \mathrm{L}$ (Figure 3d). The lowest concentration of dissolved oxygen in RW was recorded in the summer of $2018\left(0.61 \pm 0.36 \mathrm{mgO}_{2} / \mathrm{L}\right)$, while the highest concentration in UV-TW was found in the summer of $2017\left(10.02 \pm 0.34 \mathrm{mgO}_{2} / \mathrm{L}\right)$.

Table 2 shows the evolution of COD in RW and UV-TW. It varies between $722.56 \pm$ $11.43 \mathrm{mgO}_{2} / \mathrm{L}$ (autumn of 2017) and $1344.90 \pm$ $18.38 \mathrm{mgO}_{2} / \mathrm{L}$ (summer of 2018) with an average value of $1059 \pm 19.2 \mathrm{mgO}_{2} / \mathrm{L}$ for RW. For UV-TW, the highest concentration was recorded in the summer of $2017\left(117.35 \pm 3.48 \mathrm{mgO}_{2} / \mathrm{L}\right)$ and the lowest in the autumn of 2018 (39.44 \pm $2.28 \mathrm{mgO}_{2} / \mathrm{L}$ ). The average concentration of $\mathrm{BOD}_{5}$ in $\mathrm{RW}$ is around $469.73 \pm 15.7 \mathrm{mgO}_{2} / \mathrm{L}$, the 
Table 2. Seasonal variation in oxidizable pollution at the Aourir wastewater treatment plant over the years 2017-2018

\begin{tabular}{|c|c|c|c|c|c|c|c|c|c|c|c|c|c|}
\hline Season & $\begin{array}{l}\text { Para- } \\
\text { meters }\end{array}$ & $\begin{array}{c}\mathrm{COD} \\
\mathrm{mg} \mathrm{O}_{2} / \mathrm{l}\end{array}$ & $\begin{array}{c}\mathrm{COD} \\
\mathrm{mg} \mathrm{O}_{2} / \mathrm{l}\end{array}$ & $\begin{array}{l}\text { Limit } \\
\text { of } \\
\text { direct } \\
\text { dis- } \\
\text { charge } \\
\mathrm{COD} \\
\mathrm{mg} \\
\mathrm{O}_{2} / 1\end{array}$ & $\begin{array}{l}\text { Remo- } \\
\text { val } \\
\text { percen- } \\
\text { tage }\end{array}$ & $\begin{array}{c}\mathrm{BOD}_{5} \\
\mathrm{mg}^{\mathrm{O}} / \mathrm{l}\end{array}$ & $\begin{array}{c}\mathrm{BOD}_{5} \\
\mathrm{mg}_{2} / \mathrm{I}\end{array}$ & $\begin{array}{l}\text { Limit } \\
\text { of } \\
\text { direct } \\
\text { dis- } \\
\text { charge } \\
\mathrm{mg} \\
\mathrm{BOD}^{5} \\
\mathrm{O}_{2} / \mathrm{I}^{5}\end{array}$ & $\begin{array}{l}\text { Remo- } \\
\text { val } \\
\text { percen- } \\
\text { tage }\end{array}$ & $\begin{array}{c}\mathrm{SS} \\
\mathrm{mg} / \mathrm{l}\end{array}$ & $\begin{array}{c}\mathrm{SS} \\
\mathrm{mg} / \mathrm{l}\end{array}$ & $\begin{array}{l}\text { Limit } \\
\text { of } \\
\text { direct } \\
\text { dis- } \\
\text { charge } \\
\text { SS mg } \\
\mathrm{O}_{2} / \mathrm{I}\end{array}$ & $\begin{array}{l}\text { Remo- } \\
\text { val } \\
\text { percen- } \\
\text { tage }\end{array}$ \\
\hline & & RW & UV-TW & \multirow{8}{*}{500} & \multirow[b]{2}{*}{$89.40 \%$} & RW & $\begin{array}{l}\text { UV- } \\
\text { TW }\end{array}$ & \multirow{8}{*}{100} & \multirow[b]{2}{*}{$95.20 \%$} & RW & $\begin{array}{l}\text { UV- } \\
\text { TW }\end{array}$ & \multirow{8}{*}{50} & \multirow[b]{2}{*}{$96.80 \%$} \\
\hline $\begin{array}{c}\text { Spring } \\
2017\end{array}$ & $\begin{array}{c}\text { Min } \\
\text { Max } \\
\text { Average } \\
\text { SD }\end{array}$ & $\begin{array}{c}963.67 \\
1083 \\
1023.30 \\
19.65\end{array}$ & $\begin{array}{c}83.33 \\
132.66 \\
108 \\
3.89\end{array}$ & & & $\begin{array}{c}336 \\
415.33 \\
375.66 \\
10.26\end{array}$ & \begin{tabular}{|c|}
13.33 \\
23 \\
18.16 \\
3.81
\end{tabular} & & & $\begin{array}{c}376.33 \\
492.33 \\
434.33 \\
10.81\end{array}$ & $\begin{array}{c}9 \\
18.66 \\
13.83 \\
2.25\end{array}$ & & \\
\hline $\begin{array}{c}\text { Summer } \\
2017\end{array}$ & $\begin{array}{c}\text { Min } \\
\text { Max } \\
\text { Average } \\
\text { SD }\end{array}$ & $\begin{array}{c}905 \\
1121.30 \\
1045.30 \\
21.50\end{array}$ & $\begin{array}{c}40.73 \\
160 \\
117.35 \\
3.84\end{array}$ & & $88.80 \%$ & $\begin{array}{c}355.33 \\
484.33 \\
437.66 \\
18.63\end{array}$ & $\begin{array}{c}10 \\
51.33 \\
28.88 \\
4.02 \\
\end{array}$ & & $93.40 \%$ & $\begin{array}{c}477 \\
728.33 \\
573.77 \\
6.18\end{array}$ & $\begin{array}{c}4.66 \\
19 \\
11.55 \\
2.08\end{array}$ & & $98.00 \%$ \\
\hline $\begin{array}{c}\text { Autumn } \\
2017\end{array}$ & $\begin{array}{c}\text { Min } \\
\text { Max } \\
\text { Average } \\
\text { SD }\end{array}$ & $\begin{array}{c}645 \\
771.67 \\
722.56 \\
11.43\end{array}$ & $\begin{array}{c}86 \\
126.66 \\
104.22 \\
3.54\end{array}$ & & $85.60 \%$ & $\begin{array}{c}395 \\
463.33 \\
418.55 \\
13.24\end{array}$ & \begin{tabular}{|c|}
6 \\
38.33 \\
18.55 \\
2.76 \\
\end{tabular} & & $95.60 \%$ & $\begin{array}{c}383 \\
636 \\
528.33 \\
5.70\end{array}$ & $\begin{array}{c}12 \\
39.66 \\
\mathbf{2 2 . 5 5} \\
3.54\end{array}$ & & $95.70 \%$ \\
\hline $\begin{array}{c}\text { Winter } \\
2018\end{array}$ & $\begin{array}{c}\text { Min } \\
\text { Max } \\
\text { Average } \\
\text { SD }\end{array}$ & $\begin{array}{c}992 \\
1410.30 \\
1165.90 \\
12.60\end{array}$ & $\begin{array}{c}131.66 \\
170 \\
145 \\
5.34\end{array}$ & & $87.60 \%$ & $\begin{array}{c}430 \\
581.33 \\
518.66 \\
20.85\end{array}$ & \begin{tabular}{|c|}
16.33 \\
28.66 \\
23.66 \\
4.21 \\
\end{tabular} & & $95.40 \%$ & $\begin{array}{c}382.33 \\
784.33 \\
575.77 \\
8.10\end{array}$ & $\begin{array}{c}11.66 \\
14 \\
13.22 \\
1.10 \\
\end{array}$ & & $97.70 \%$ \\
\hline $\begin{array}{c}\text { Spring } \\
2018\end{array}$ & $\begin{array}{c}\text { Min } \\
\text { Max } \\
\text { Average } \\
\text { SD }\end{array}$ & $\begin{array}{c}961 \\
1131.70 \\
1054.60 \\
16.53\end{array}$ & $\begin{array}{c}25.50 \\
80.20 \\
48.56 \\
2.15\end{array}$ & & $95.40 \%$ & $\begin{array}{c}424 \\
574.66 \\
505.88 \\
14.23\end{array}$ & \begin{tabular}{|c|}
21.33 \\
32.33 \\
26.44 \\
4.04 \\
\end{tabular} & & $94.80 \%$ & $\begin{array}{c}252 \\
876.66 \\
561.77 \\
18.44\end{array}$ & $\begin{array}{c}11.33 \\
21.33 \\
16.77 \\
1.21 \\
\end{array}$ & & $97.00 \%$ \\
\hline $\begin{array}{c}\text { Summer } \\
2018\end{array}$ & $\begin{array}{c}\text { Min } \\
\text { Max } \\
\text { Average } \\
\text { SD }\end{array}$ & $\begin{array}{c}1293 \\
1400.70 \\
1344.90 \\
18.38\end{array}$ & $\begin{array}{c}43.60 \\
77.66 \\
57.20 \\
2.59\end{array}$ & & $95.70 \%$ & $\begin{array}{c}525.66 \\
604 \\
557.22 \\
26.00\end{array}$ & \begin{tabular}{|c|}
4.66 \\
27.66 \\
15.44 \\
4.80
\end{tabular} & & $97.20 \%$ & $\begin{array}{c}940.33 \\
1040.6 \\
979.77 \\
43.84\end{array}$ & $\begin{array}{c}9.33 \\
19.66 \\
13.22 \\
1.46\end{array}$ & & $98.70 \%$ \\
\hline $\begin{array}{c}\text { Autumn } \\
2018\end{array}$ & $\begin{array}{c}\text { Min } \\
\text { Max } \\
\text { Average } \\
\text { SD }\end{array}$ & $\begin{array}{c}936 \\
977.33 \\
954.67 \\
11.79\end{array}$ & $\begin{array}{c}35.46 \\
44.53 \\
39.44 \\
2.28\end{array}$ & & $95.90 \%$ & $\begin{array}{c}410.66 \\
468.66 \\
437.66 \\
8.27\end{array}$ & \begin{tabular}{|c|}
5.66 \\
23.66 \\
12.66 \\
2.15
\end{tabular} & & $97.10 \%$ & $\begin{array}{c}639 \\
687 \\
659.11 \\
22.30\end{array}$ & $\begin{array}{c}3.33 \\
26 \\
13.55 \\
2.78\end{array}$ & & $97.90 \%$ \\
\hline
\end{tabular}

highest concentration was recorded in the summer of $2018\left(557 \pm 22.26 \mathrm{mgO}_{2} / \mathrm{L}\right)$, the lowest seasonal concentration was recorded in spring $2017\left(375.66 \pm 10.26 \mathrm{mgO}_{2} / \mathrm{L}\right)$. For UV-TW, an average value does not exceed $28 \mathrm{mgO}_{2} / \mathrm{L}$, the highest concentration was recorded in the summer of $2017\left(28.88 \pm 4.02 \mathrm{mgO}_{2} / \mathrm{L}\right)$, whereas the lowest seasonal concentration is recorded in the summer of $2018\left(12.66 \pm 2.15 \mathrm{mgO}_{2} / \mathrm{L}\right)$ (Table 2). The evolution of SS in RW and UV-TW shows a strong seasonal fluctuation. For RW, it varies from $252 \pm 14.73 \mathrm{mg} / \mathrm{L}$ to $1046 \pm 50.21 \mathrm{mg} / \mathrm{L}$ for an average of $610.6 \pm 16.26 \mathrm{mg} / \mathrm{L}$. The maximum value was recorded during the third quarter of the year, which corresponds to the summer of 2018 $(979 \pm 43 \mathrm{mg} / \mathrm{L})$. For UV-TW, the SS levels vary from $3 \pm 1.15 \mathrm{mg} / \mathrm{L}$ to $39 \pm 4.04 \mathrm{mg} / \mathrm{L}$ for an average of $15.1 \pm 2.05 \mathrm{mg} / \mathrm{L}$, with the highest seasonal concentration recorded in the autumn of 2017 $(22 \pm 3.54 \mathrm{mg} / \mathrm{L})$, and the lowest recorded in the summer of 2017 (11.55 $2.08 \mathrm{mg} / \mathrm{L})$ (table 2).
The analysis of the $\mathrm{NO}^{3-}$ and $\mathrm{PO}_{4}^{3-}$ nutrient contents in the RW and UV-TW of the Aourir wastewater treatment plant (Table 3) shows that the average values are much lower than those usually found in domestic wastewater. The average concentration of $\mathrm{NO}^{3-}$ in $\mathrm{RW}$ is around $2.039 \pm 0.15 \mathrm{mg} / \mathrm{L}$, the highest seasonal concentration was recorded in the summer of 2018 $(2.36 \pm 0.45 \mathrm{mg} / \mathrm{L})$, while the lowest seasonal concentration was recorded in the autumn of 2017 $(1.3 \pm 0.35 \mathrm{mg} / \mathrm{L})$. For UV-TW, the average concentration was around $0.71 \pm 0.14 \mathrm{mg} / \mathrm{L}$, the maximum value was recorded in the autumn of 2018 $(0.9 \pm 0.14 \mathrm{mg} / \mathrm{L})$, whereas the minimum was recorded in the autumn of $2017(0.35 \pm 0.14 \mathrm{mg} / \mathrm{L})$.

The mean values for $\mathrm{PO}_{4}^{3-}$ in $\mathrm{RW}$ and UV-TW are $10.54 \mathrm{mg} / \mathrm{L} \pm 0.18$ and $7.22 \pm 0.18$, respectively. For RW, the highest seasonal concentration was recorded in the summer of $2017(12.79 \pm 0.07 \mathrm{mg} / \mathrm{L})$, the lowest seasonal concentration was recorded in the autumn of $2018(9.42 \pm 0.09 \mathrm{mg} / \mathrm{L})$. In 
Table 3. Seasonal variation of nitrates and orthophosphates pollution in the Aourir wastewater treatment plant over the years 2017-2018

\begin{tabular}{|c|c|c|c|c|c|c|c|c|c|}
\hline Season & Parameters & $\begin{array}{c}\mathrm{NO}^{3-} \\
(\mathrm{mg} / \mathrm{L})\end{array}$ & $\begin{array}{c}\mathrm{NO}^{3-} \\
(\mathrm{mg} / \mathrm{L})\end{array}$ & $\begin{array}{l}\text { Limit of direct } \\
\text { discharge } \\
\mathrm{NO}^{3-}(\mathrm{mg} / \mathrm{L})\end{array}$ & $\begin{array}{l}\text { Removal } \\
\text { percentage }\end{array}$ & $\begin{array}{l}\mathrm{PO}_{4}^{3-} \\
(\mathrm{mg} / \mathrm{L})\end{array}$ & $\begin{array}{l}\mathrm{PO}_{4}^{3-} \\
(\mathrm{mg} / \mathrm{L})\end{array}$ & $\begin{array}{c}\text { Limit of direct } \\
\text { discharge } \\
\mathrm{PO}_{4}^{3-}(\mathrm{mg} / \mathrm{L})\end{array}$ & $\begin{array}{l}\text { Removal } \\
\text { percentage }\end{array}$ \\
\hline & & RW & UV-TW & & & RW & UV-TW & & \\
\hline \multirow{4}{*}{$\begin{array}{l}\text { Spring } \\
2017\end{array}$} & Min & 1,52 & 0,94 & \multirow{28}{*}{30} & \multirow{4}{*}{$39 \%$} & 10,56 & 7,24 & \multirow{28}{*}{10} & \multirow{4}{*}{$34 \%$} \\
\hline & Max & 1,28 & 0,78 & & & 13,09 & 8,26 & & \\
\hline & Average & 1,37 & 0,84 & & & 11,59 & 7,62 & & \\
\hline & SD & 0,08 & 0,13 & & & 0,08 & 0,07 & & \\
\hline \multirow{4}{*}{$\begin{array}{c}\text { Summer } \\
2017\end{array}$} & Min & 2,12 & 0,3 & & \multirow{4}{*}{$65 \%$} & 11,84 & 7,26 & & \multirow{4}{*}{$34 \%$} \\
\hline & Max & 2,33 & 1,14 & & & 13,71 & 9,19 & & \\
\hline & Average & 2,2 & 0,76 & & & 12,79 & 8,45 & & \\
\hline & SD & 0,04 & 0,06 & & & 0,07 & 0,06 & & \\
\hline \multirow{4}{*}{$\begin{array}{c}\text { Autumn } \\
2017\end{array}$} & Min & 1,13 & 0,31 & & \multirow{4}{*}{$73 \%$} & 8,53 & 7,24 & & \multirow{4}{*}{$17 \%$} \\
\hline & Max & 1,45 & 0,42 & & & 11,2 & 8,99 & & \\
\hline & Average & 1,3 & 0,35 & & & 9,9 & 8,19 & & \\
\hline & SD & 0,11 & 0,14 & & & 0,18 & 0,04 & & \\
\hline \multirow{4}{*}{$\begin{array}{l}\text { Winter } \\
2018\end{array}$} & Min & 1,38 & 0,65 & & \multirow{4}{*}{$57 \%$} & 10,83 & 7,52 & & \multirow{4}{*}{$32 \%$} \\
\hline & Max & 1,84 & 0,8 & & & 12,96 & 8,34 & & \\
\hline & Average & 1,66 & 0,71 & & & 11,57 & 7,9 & & \\
\hline & SD & 0,16 & 0,16 & & & 0,07 & 0,15 & & \\
\hline \multirow{4}{*}{$\begin{array}{c}\text { Spring } \\
2018\end{array}$} & Min & 1,1 & 0,47 & & \multirow{4}{*}{$54 \%$} & 10,43 & 7,38 & & \multirow{4}{*}{$31 \%$} \\
\hline & Max & 1,77 & 0,87 & & & 11,55 & 8,24 & & \\
\hline & Average & 1,51 & 0,69 & & & 11,13 & 7,7 & & \\
\hline & SD & 0,15 & 0,13 & & & 0,25 & 0,08 & & \\
\hline \multirow{4}{*}{$\begin{array}{c}\text { Summer } \\
2018\end{array}$} & Min & 2,08 & 0,43 & & \multirow{4}{*}{$77 \%$} & 8,4 & 1,38 & & \multirow{4}{*}{$50 \%$} \\
\hline & Max & 2,51 & 0,69 & & & 10,14 & 7,2 & & \\
\hline & Average & 2,36 & 0,54 & & & 10,02 & 5,01 & & \\
\hline & SD & 0,14 & 0,14 & & & 0,1 & 0,52 & & \\
\hline \multirow{4}{*}{$\begin{array}{c}\text { Autumn } \\
2018\end{array}$} & Min & 2,06 & 0,77 & & \multirow{4}{*}{$65 \%$} & 8,51 & 1,56 & & \multirow{4}{*}{$81 \%$} \\
\hline & Max & 3,15 & 1,01 & & & 10,4 & 1,96 & & \\
\hline & Average & 2,6 & 0,9 & & & 9,42 & 1,77 & & \\
\hline & SD & 0,15 & 0,14 & & & 0,09 & 0,06 & & \\
\hline
\end{tabular}

UV-TW, $8.45 \pm 0.06 \mathrm{mg} / \mathrm{L}$ is the highest seasonal concentration of $\mathrm{PO}_{4}^{3-}$ recorded in the summer of 2017 and $1.77 \pm 0.06 \mathrm{mg} / \mathrm{L}$ is the lowest seasonal concentration recorded in the autumn of 2018 (Table 3).

The measured data of physicochemical parameters were statistically analyzed using ANOVA. The statistical analysis indicates high significant difference between seasons of all measured parameters $p<0.001$, in all types of water. In addition, a high significant difference is observed between steps of treatment $p<0.001$.

\section{Typology of Aourir waters}

Table 4 shows that the values recorded for the $\mathrm{COD} / \mathrm{BOD}_{5}$ ratio is $2.25 \pm 0.22$. The $\mathrm{BOD}_{5} / \mathrm{COD}$ values recorded during the study period range from 0.37 to 0.58 . The $\mathrm{SS} / \mathrm{BOD}_{5}$ ratio is in order of $1.34 \pm 0.18$ in 2017 and 2018 . The obtained results indicate that the OM concentrations are significant; the highest concentration is recorded in summer 2018 (819.78 $\mathrm{mg} / \mathrm{L}$ ) (Table 4); the mean value was $660.48 \pm 77.01 \mathrm{mg} / \mathrm{L}$. This result, as well as the other ratios, reflect the relatively high loads of organic matter transported by the Aourir effluent.

\section{The bacteriological characteristics of the wastewater and the purified water of the Aourir station}

The bacteriological analysis focused on monitoring fecal contamination germs, total coliforms, fecal coliforms, E. coli and fecal streptococci (Enterococci). The results presented in this section corresponds to the sampling period of 2017 and 2018 in RW, BTW and UV-TW for a 
Table 4. Oxidizable matter and biodegradability of the Aourir wastewater effluent

\begin{tabular}{|l|c|c|c|c|c|c|c|c|c|c|c|}
\hline $\begin{array}{c}\text { Parameters } \\
\text { studied }\end{array}$ & $\begin{array}{c}\text { Spring } \\
2017\end{array}$ & $\begin{array}{c}\text { Summer } \\
2017\end{array}$ & $\begin{array}{c}\text { Autumn } \\
2017\end{array}$ & $\begin{array}{c}\text { Winter } \\
2018\end{array}$ & $\begin{array}{c}\text { Spring } \\
2018\end{array}$ & $\begin{array}{c}\text { Summer } \\
2018\end{array}$ & $\begin{array}{c}\text { Autumn } \\
2018\end{array}$ & Min & Max & $\begin{array}{c}\text { Average } \\
n=7\end{array}$ & SD \\
\hline COD/BOD $_{5}$ & 2,72 & 2,39 & 1,73 & 2,25 & 2,08 & 2,41 & 2,18 & 1,73 & 2,72 & 2,25 & 0,22 \\
\hline BOD $_{5} / \mathrm{COD}$ & 0,37 & 0,42 & 0,58 & 0,44 & 0,48 & 0,41 & 0,46 & 0,37 & 0,58 & 0,46 & 0,05 \\
\hline $\mathrm{SS}_{\mathrm{BOD}}$ & 1,16 & 1,31 & 1,26 & 1,11 & 1,11 & 1,76 & 1,51 & 1,11 & 1,76 & 1,34 & 0,18 \\
\hline $\mathrm{OM}$ & 591,56 & 640,22 & 519,89 & 734,41 & 688,78 & 819,78 & 610,00 & 519,89 & 819,78 & 660,48 & 77,01 \\
\hline
\end{tabular}

(a)
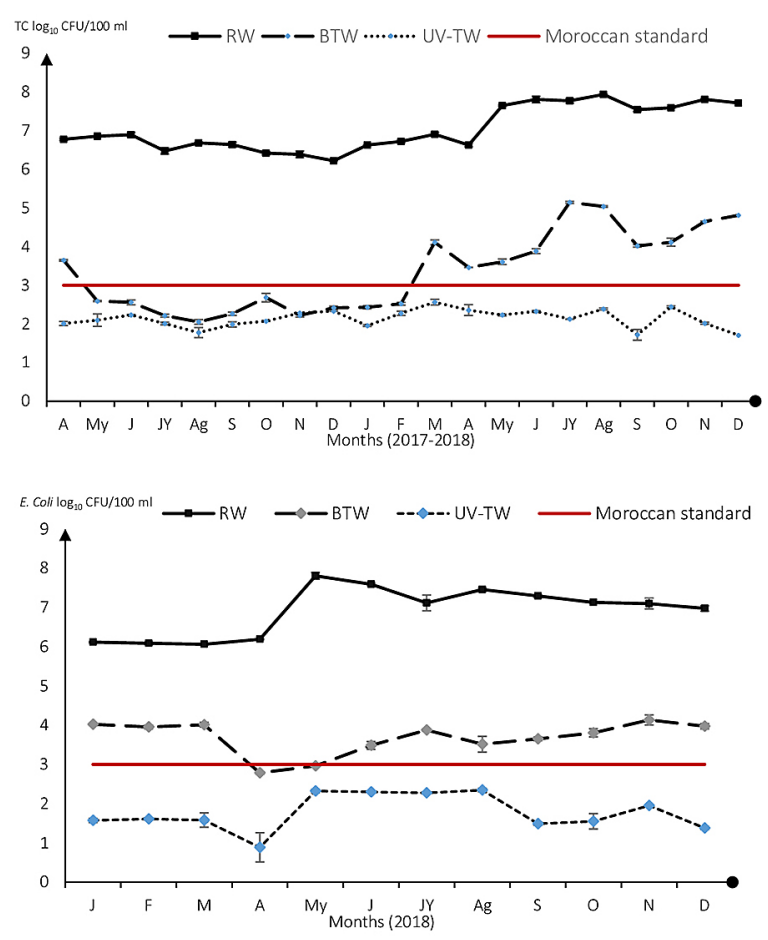

(c) (b)
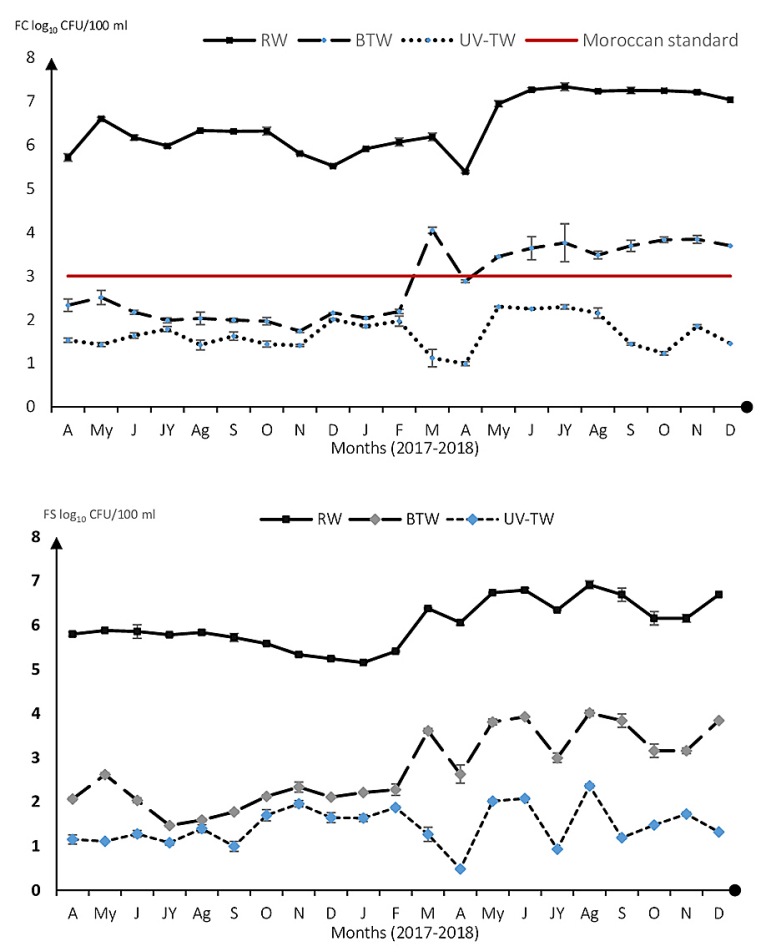

(d)

Figure 4. Monthly variation of bacteriological parameters during the sampling period

a) Total Coliforms (TC), b) Fecal Coliforms (FC), c) Escherichia coli (E. coli), d) Fecal Streptococci (FS)

possible evaluation of their abatement. The bacterial load in RW and UV-TW shows a strong fluctuation during the different seasons of the two sampling years for all bacterial parameters $\mathrm{p}<0.001$. The highest concentration of total coliforms in RW was recorded in the summer of 2018 by $7.75 \log _{10} \mathrm{CFU} / 100 \mathrm{ml}$, and the lowest was recorded in the winter of 2017 by 6.36 $\log _{10} \mathrm{CFU} / 100 \mathrm{ml}$ (Figure $4 \mathrm{a}$ ). The annual average of total coliforms in RW is approximately $7.05 \log _{10} \mathrm{CFU} / 100 \mathrm{ml}$. This number decreases considerably in BTW with a value of $3.35 \log _{10}$ $\mathrm{CFU} / 100 \mathrm{ml}$ and in UV-TW with a value of $2.13 \log _{10} \mathrm{CFU} / 100 \mathrm{ml}$. The highest concentration of total coliforms in UV-TW was recorded in the spring of 2018 with a value of $2.30 \log _{10}$ $\mathrm{CFU} / 100 \mathrm{ml}$, and the lowest was recorded in the summer of 2017 with a value of $1.92 \log _{10}$ CFU/100 ml.

The average fecal coliform load in RW is about $6.47 \log _{10} \mathrm{CFU} / 100 \mathrm{ml}$ and $1.67 \log _{10} \mathrm{CFU} / 100 \mathrm{ml}$ in UV-TW (Figure $4 \mathrm{~b}$ ). The highest concentration of fecal coliforms in RW was recorded in the summer of 2018 (7.27 $\left.\log _{10} \mathrm{CFU} / 100 \mathrm{ml}\right)$, while the lowest was marked in the autumn of 2017 (5.88 $\log _{10}$ CFU/100 ml). The fecal coliform concentrations in UV-TW reached the maximum in the summer of $2018\left(1.96 \log _{10} \mathrm{CFU} / 100 \mathrm{ml}\right)$ and the lowest abundance was recorded in the autumn of $2018\left(1.51 \log _{10}\right.$ CFU/100 ml).

For E. coli, a one-year sampling was performed from January 2018 to December 2018 (Figure $4 \mathrm{c}$ ). In RW, it shows an annual average concentration of $6.9 \log _{10} \mathrm{CFU} / 100 \mathrm{ml}$, the 
highest concentration was marked in the summer season of 2018 (7.28 $\log _{10}$ CFU/100 ml), while the lowest concentration was recorded in the winter of $2018\left(6.08 \log _{10} \mathrm{CFU} / 100 \mathrm{ml}\right)$. UV-TW does not exceed $1.77 \log _{10} \mathrm{CFU} / 100 \mathrm{ml}$ as an annual average value, the highest load is recorded in the summer of $2018\left(2.03 \log _{10} \mathrm{CFU} / 100 \mathrm{ml}\right)$, and the lowest was recorded in the winter of 2018 $\left(1.58 \log _{10} \mathrm{CFU} / 100 \mathrm{ml}\right)$.

The average number of fecal streptococci in RW is $6.02 \log _{10} \mathrm{CFU} / 100 \mathrm{ml}$, while UV-TW contain an average value of less than $2 \log _{10}$ CFU/100 ml (Figure $4 \mathrm{~d}$ ). The highest concentration of fecal streptococci in RW was recorded in the summer of $2018\left(6.65 \log _{10}\right.$ CFU/100 ml) while the lowest concentration was recorded in the autumn of 2017 (5.38 $\left.\log _{10} \mathrm{CFU} / 100 \mathrm{ml}\right)$. UVTW recorded the highest abundance in the autumn of 2017 with a value of $1.76 \log _{10}$ CFU/100 ml, and the lowest in the summer of 2017 with a value of $1.15 \log _{10}$ CFU/100 ml (Figure $4 \mathrm{~d}$ ). According to the statistical study, a significant difference $\mathrm{p}<0.001$ between RW and UV-TW was found for the four indicators of fecal contamination.

\section{DISCUSSION}

\section{Physicochemical parameters}

Agadir is among the regions of the Moroccan kingdom most affected by the scarcity of conventional water resources. The reuse of treated wastewater seems a necessity to reduce the pressure on the groundwater. Currently, UV-TW from the Aourir wastewater treatment plant is reused to irrigate a golf course in Taghazout bay tourist resort. This study gives the bacteriological and the physicochemical quality of UV-TW, to evaluate the effectiveness of UV disinfection and to prevent their health and environmental risks.

Throughout the study period, the temperature of all types of water was below $30^{\circ} \mathrm{C}$, which are favorable values for the operation of bioreactors (Adouani et al., 2015). The high fluctuation observed is due to climate change, the treatment stages, and the chemical and biological reactions. These recorded temperatures do not exceed the limit values for direct discharges to the receiving environment (Official Bulletin, 2002).Water temperature is an ecological factor with significant ecological impacts (Makhoukh et al., 2011). It is important in the aquatic environment and has an influence on physicochemical and biological reactions (Chapman, 1996). Bourouache et al., (2019), who monitored the performance of a percolation infiltration system in the same region, found that temperature is always below $35^{\circ} \mathrm{C}$ in different types of water, and concluded that this temperature is adequate for the proper functioning of anaerobic sludge digestion. The $\mathrm{pH}$ values in the different types of water are close to neutral. In general, despite the observed fluctuations, the $\mathrm{pH}$ evolution (UV-TW) is always between 6.5 and 8.4, which are considered limit values for direct discharges into the natural environment and a normal $\mathrm{pH}$ zone according to the quality standard for water intended for irrigation (Official Bulletin, 2002). In Algeria, a comparison study of two free biomass treatment plants (aerated lagoon and activated sludge) concluded that there is an asymmetric distribution of the $\mathrm{pH}$ values in both treatment plants. The aerated lagoon reflects an asymmetric distribution towards low $\mathrm{pH}$ concentrations, whereas the activated sludge reflects an asymmetric distribution towards high $\mathrm{pH}$ concentration values (Bachi et al., 2020). However, it should be noted that the $\mathrm{pH}$ values that are too acidic or too basic could affect the biological treatment processes. In this regard, Deronzier et al., (2002) reported that a drop in $\mathrm{pH}$ below 7 significantly slows nitrification. In addition, the $\mathrm{pH}$ values ranging from 5.6 to 8.6 promote the bacterial growth necessary for the biological degradation of organic pollutants (Maiga et al., 2006). The $\mathrm{pH}$ between 6.5 and 7.5 is generally recommended for wastewater treatment plants, as low $\mathrm{pH}$ promotes the growth of filamentous fungi and other organisms responsible for sludge flotation (Arcand et al., 2005).

The strong fluctuation of the electrical conductivity recorded in the RW and UV-TW can be explained by the removal of a high concentration of ions throughout the activated sludge treatment process. Contrary to the M'zar plant in the same region equipped with a percolation infiltration system, several authors - Bourouache et al., (2019); Et-Taleb et al., (2014); El Haouti et al., (2015) - have recorded an increase in the concentration of electrical conductivity in the treated water at the outlet of the WWTP. They have enhanced this growth by the mineralization of organic matter by bacteria during the treatment process and by the chemical and geometrical properties of the use of sand in the percolation infiltration basins. The results obtained in this study are consistent with the 
work carried out on the Yemen activated sludge plant in an arid climate; this study concluded that electrical conductivity is slightly reduced by the treatment system, and that physical and biological treatments have a reduced effect on electrical conductivity (Merghem et al., 2016). The quality standards for irrigation water allows deducing that treated wastewater is acceptable for crop irrigation. Similarly, these average values are below $2700 \mu \mathrm{S} / \mathrm{cm}$, which is considered the limit value for direct discharge into the receiving environment (Official Bulletin, 2002).

A strong increase in the concentration of dissolved oxygen in UV-TW is due to a good aeration of water, necessary for the development of aerobic microorganisms ensuring the oxidation of organic matter (Deronzier et al., 2002). However, in an activated sludge wastewater treatment, the dissolved oxygen (DO) contained in the treated water must be higher than $2 \mathrm{mg} / 1$ (Merghem et al., 2016). The respect of these thresholds $\left(\mathrm{O}_{2}>\right.$ $2 \mathrm{mg} / \mathrm{l})$ creates favorable conditions for both total aerobic biodegradation and the establishment of the nitrification phenomena. It is important to note that dissolved oxygen is a good indicator of the degree of water pollution and the presence of aerobic bacteria capable of developing in the environment.

The suspended solids (SS) concentrations continue to change especially in spring and summer. In addition, the effluents from the Aourir plant reflect remarkable particulate pollution, especially in summer, which is explained by a major hydraulic spill due to significant domestic and tourist activity in the region. The recorded values remain below the direct discharge limit value $(50 \mathrm{mg} / \mathrm{L})$ throughout the monitoring period (Official Bulletin, 2002). It should be noted that suspended solids represent all mineral and organic particles contained in the water. It depends on the nature of the land crossed, the season, the precipitation, the nature of the discharges, etc. (Rodier et al., 1959). It causes the water turbidity and a reduction in light penetration. Turbidity also indicates the presence of suspended solids, but high turbidity allows microorganisms to attach to suspended particles, which protects them from treatment (Mouhanni et al., 2013). The removal of suspended solids was able to reach a maximum of $98 \%$ total removal in the UV-TW that underwent final filtration. This result is even higher than that of Hamoda et al., (2004) which managed to reach $70 \%$ removal of suspended solids after secondary water filtration. The same is true for Petala et al., (2006), who managed to achieve a turbidity removal percentage of about $45 \%$ after sand filtration, while the activated carbon process increased turbidity removal to more than $60 \%$. The study conducted by Bachi et al., (2020) on the performance comparison of two free biomass treatment systems (aerated lagoon, activated sludge), showed that the SS removal rates were highest in the case of the activated sludge system $(96.6 \%-93.4 \%)$ and the lowest in the case of aerated lagoon system $(39.2 \%-67 \%)$ with an average difference of more than $43 \%$. These results allow concluding that the combination of the investigated treatment system was successful in removing particulate pollution.

The importance of monitoring organic pollution parameters is summarized by the fact that $\mathrm{BOD}_{5}$ (Biochemical Oxygen Demand) allows the evaluation of biodegradable organic matter present in water (Hassoune et al., 2006). COD (Chemical Oxygen Demand) is used to assess the concentration of organic or mineral matter dissolved or suspended in water, through the amount of oxygen necessary for their total chemical oxidation (Rodier et al., 1959). The results of biological oxygen demand $\left(\mathrm{BOD}_{5}\right)$ and chemical oxygen demand (COD) are related empirically to the oxidizable matter (Bali et al., 2010). An increase in the organic load was noticed during the second year of sampling and significant difference was recorded between the two sampling years $p<0.001$ (2017-2018). The concentrations of $\mathrm{BOD}_{5}$ and COD in UV-TW are less than $100 \mathrm{mg} \mathrm{O}_{2} / \mathrm{L}$ and $500 \mathrm{mg} \mathrm{O}_{2} / \mathrm{L}$, respectively, considered as a limit values for direct discharges into the natural environment. The treatment efficiency of the Aourir activated sludge can be summed up by the $95.5 \%$ and $91.8 \%$ abatement recorded for $\mathrm{BOD}_{5}$ and $\mathrm{COD}$, respectively. A great concordance between the obtained results and those of Abdulla et al., (2020), who worked on activated sludge system in Jordan, were noticed. They found that $\mathrm{BOD}_{5}$ comes out with average values of $25 \mathrm{mg} \mathrm{O}_{2} / \mathrm{L}$, and COD reaches an average value of $120 \mathrm{mg} \mathrm{O}_{2} / \mathrm{L}$; these results were taken in 2017/2018 in the same period of our study.

The Agadir region has several treatment plants that treat most of the region's effluents. In order to have a general view on the treatment efficiency of the Aourir plant, it is interesting to compare the activated sludge system with other treatment systems in the region. Mimouni et al., 
(2011) followed the efficiency of percolation infiltration in the Bensergao plant. The organic pollution abatement was very interesting; $\mathrm{BOD}_{5}$ reaches a rate of $99.9 \%$ and $92.8 \%$ for COD. Mouhanni et al., (2013) followed the M'zar plant also equipped with a percolation infiltration system and showed an important treatment efficiency with a $\mathrm{BOD}_{5}$ reduction rate of $98 \%$ and $98 \%$ for COD, Bourouache et al., (2019) continued the follow-up and confirmed the efficiency of the fixed biomass treatment (Table 8). The COD/ $\mathrm{BOD}_{5}$ ratio is a very important factor in assessing the biodegradability of the wastewater. The ratio is below 3 which designates a domestic effluent indicating a good biodegradability of the oxidizable material (Boutayeb et al., 2012). The $\mathrm{BOD}_{5} /$ COD ratio, gives more indication of the origin of wastewater pollution and its treatment possibilities (Benyakhlef et al., 2007). The values recorded show a high organic load and confirm the possibility of an easy biological treatment, being higher than 0.3. The $\mathrm{BOD}_{5} / \mathrm{COD}$ ratio indicates a dominance of organic matter (Bouknana et al., 2014). The $\mathrm{SS} / \mathrm{BOD}_{5}$ ratio remains within the normal range between one and three. The ratio confirmed the organicity of the effluent and provided the information on sludge production (Quevedo et al., 2012). The term "oxidizable matter" (OM) corresponds to a weighted average of two global parameters the $\mathrm{COD}$ and the $\mathrm{BOD}_{5}$, by assigning a double coefficient to $\mathrm{BOD}_{5}$ (Rodier et al., 1959). The OM is a very useful parameter for assessing the pollutant load and possibility of connection of industrial plant to the municipal sewerage network. In reality, most organic materials become polluting only when they are found in excess in the environment (Bouknana et al., 2014).

Nitrate is the final product of aerobic stabilization of nitrogen compounds. It is considered the most stable oxygen compound present in water. In natural resources, the nitrate levels are often low $(<20 \mathrm{mg} / \mathrm{l})$ (Baharvand \& Daneshvar, 2019). The discharge of large amounts of wastewater is the most important source of nitrate to surface water more than to groundwater. The results of the nitrate content measurement of RW and UV-TW in the Aourir plant showed that the amount of nitrate in the treatment process is reduced. Moreover, they have indicated an acceptable result according to environmental standard threshold $(<30 \mathrm{mg} / \mathrm{l})$. Consequently, the $\mathrm{NO}_{3}{ }^{-}$removal efficiency is estimated at $63 \%$ during the water treatment process in the Aourir treatment plant. The concentrations of orthophosphates have significantly decreased in UV-TW; these values remain below the direct discharge limit value $(10 \mathrm{mg} / \mathrm{L})$ which demonstrates the purifying power of the activated sludge technique. However, this decrease is insufficient because it would be necessary to reach the values in the range of 0.6 to $1 \mathrm{mg} / \mathrm{L}$ to have a water with the same phosphate content as that existing in Moroccan rivers (Mimouni et al., 2011). The $\mathrm{PO}_{4}{ }^{3-}$ removal efficiency is estimated at $39 \%$ at the exit of the Aourir plant.

\section{Bacteriological parameters}

Water disinfection is a treatment that aims to reduce the presence of pathogenic microorganisms in water. In order to comply with Moroccan standards, the Aourir plant uses UV radiation to disinfect BTW. Several criteria affect the effectiveness of UV treatment, with the insufficient energy dose damaging the genetic material of the organism rather than destroying it (Collivignarelli et al., 2018). High SS can significantly reduce the effectiveness of UV disinfection (Sharrer et al., 2005). In this sense, previous studies have shown that certain types of bacteria can easily pass through the treatment process while remaining viable (Fonteneau et al., 2017). TC, FC, E. coli and FS enumeration results at the RW levels of the Aourir plant represent a maximum bacterial load of $7.75 \log _{10} \mathrm{CFU} / 100 \mathrm{ml}, 7.27 \log _{10}$ CFU/100 ml, $7.28 \log _{10}$ CFU/100 ml, $6.65 \log _{10}$ CFU/100 ml, respectively. This load is of the same order of magnitude as that generally found in urban effluent (Shahalam, 1989; Mezrioui \& Baleux, 1994). In UV-TW, the bacterial load is lower than in RW, the average concentration of TC, FC, E. coli, and FS is $2.13 \log _{10} \mathrm{CFU} / 100 \mathrm{ml}$, $1.67 \log _{10} \mathrm{CFU} / 100 \mathrm{ml}, 1.77 \log _{10} \mathrm{CFU} / 100 \mathrm{ml}$, $2 \log _{10}$ CFU/100 ml. This research showed that the UV disinfection of the Aourir plant was sufficient to provide the water that meets the Moroccan standards. The combination of UV disinfection and microfiltration gave interesting results. After treatment, wastewater poses a potential risk to human health and the environment, so constant monitoring is necessary. The obtained results were compared with those of Petala et al., (2006), who worked with a conventional activated sludge process followed by a system composed of a moving bed sand filter, a granular activated carbon adsorption bed and ozonation system as tertiary treatment. They indicated that an ozone 
concentration of $7.1 \mathrm{mg} / \mathrm{L}$ in secondary effluents provoked a reduction of total coliforms to about $2.6 \log _{10}$; fecal coliforms to about $3.3 \log _{10}$; and to $0.7 \log _{10}$ of fecal streptococci. These results indicate that the disinfection applied in our case (UV) also has an effect close to that of ozonation. In turn, Lazarova et al., (1998), who studied disinfection technologies, indicated that 3-log removal of total coliforms, fecal coliforms and fecal streptococci were obtained by peracetic acid at $10 \mathrm{mg} / \mathrm{L}$ for a contact time of $10 \mathrm{~min}$, by UV radiation at $35 \mathrm{~mW} . \mathrm{s} / \mathrm{cm}^{2}$. Despite these results, ozonation has the advantage of having a significant effect on all types of bacteriophages and protozoan cysts, even when low treatment doses and short contact times are applied. Climatic conditions play an important role in the treatment process (Joel et al., 2018), which is most evident in monthly temperature fluctuations. Indeed, during the summer seasons of the study, significant loads were recorded. In the Aourir plant, it appears that the initial bacterial loads and climate change were the main factors influencing the bacteriological quality of the treated effluent. In Morocco, there is no standard for fecal streptococci. Although these organisms are very useful in providing more information on fecal contamination in the water (Boehm et al., 2014). It is therefore necessary to ensure continuous monitoring to assess the effect of seasonal variations on the different bacterial loads. The FC/FS ratio is a more valuable information tool for assessing sources of pollution than using the FC densities alone (Raji et al., 2015). Geldreich (1966) indicated that this ratio (FC/FS) could be used to differentiate between the contaminations from human sources, $(\mathrm{FC} / \mathrm{FS}>4)$, domestic animals (FC/FS between 0.1 and 0.6$)$, and wildlife $(\mathrm{FC} / \mathrm{FS}<0.1)$. In the performed study, the ratio of $\mathrm{FC} / \mathrm{FS}$ is around 3.39 , which allows deducing that most of the pollution is of human origin. The abatement rates for fecal contamination indicators, recorded in the Aourir plant, are in agreement with the values found in the literature, which show that biological processes can reduce coliform abundance from 3 to 4 logarithmic units. It is in the order of $90 \%$ for activated sludge (Omura et al., 1989), 99\% for extended activated sludge and for fixed culture reactors, and 99\% for lagooning (Finch et al., 1986). These abatement rates are related to the settling rate, the hydraulic residence time, and the quality of the raw wastewater. In the case of this study, the rate of reduction of fecal contamination indicators seems very important for the different parameters. The efficiency of the treatment of Total Coliforms, Fecal Coliforms, Escherichia coli, Fecal Streptococci is in the order of 4.92; 4.8; 5.13 and $4.57 \log _{10}$ respectively, which equals an efficiency of $99.99 \%$ for all parameters. Therefore, it can be deduced that the adopted treatment represents a high efficiency and performance.

\section{Correlation between physicochemical and microbiological parameters of raw and treated wastewater}

The correlations between physicochemical and bacteriological parameters for both types of water (RW, UV-TW) are detailed in Table 6 and 7. For RW, the physicochemical parameters were not significantly correlated with the concentrations of TC, FC, FS and E. coli except for conductivity which is significantly correlated with the TC concentrations $(\mathrm{r}=0.612, \mathrm{p}=0.034)$. For UV-TW, $\mathrm{FC}$ and $E$. coli concentrations have significant positive correlation with electrical conductivity and dissolved oxygen. For FC, a correlation of $(\mathrm{r}=0.659, \mathrm{p}=0.020)$ with electrical conductivity, and $(\mathrm{r}=0.712, \mathrm{p}=0.009)$ with dissolved oxygen. $E$. coli has a correlation of $(\mathrm{r}=0.695, \mathrm{p}=0.012)$ with electrical conductivity and $(\mathrm{r}=0.602, \mathrm{p}=0.038)$ with dissolved oxygen. SF also represents a significant positive correlation with dissolved oxygen of $(\mathrm{r}=0.797, \mathrm{p}=0.002)$. The correlation between the physicochemical and microbiological parameters did not show a high correlation except for the dissolved oxygen and the electric conductivity. Contrary to Pearson et al., (1987)

Table 5. Abatement of Bacteriological parameters

\begin{tabular}{|l|c|c|c|c|c|}
\hline \multicolumn{1}{|c|}{ Type of water } & RW & BTW & UV-TW & Abatement U-log & Abatement $\%$ \\
\hline TC $\log _{10}$ CFU $/ 100 ~ m l$ & $7,05 \pm 0,18$ & $3,35 \pm 0.04$ & $2,13 \pm 0.05$ & 4,92 & 99.99 \\
\hline FC $\log _{10}$ CFU/100 ml & $6,47 \pm 0.04$ & $2,83 \pm 0.09$ & $1,67 \pm 0.06$ & 4,8 & 99.99 \\
\hline E. coli $\log _{10}$ CFU/100 ml & $6,9 \pm 0.05$ & $3,68 \pm 0.06$ & $1,77 \pm 0.08$ & 5,13 & 99.99 \\
\hline FS $\log _{10}$ CFU/100 ml & $6,02 \pm 0.05$ & $2,74 \pm 0.06$ & $1,45 \pm 0.06$ & 4,57 & 99.99 \\
\hline
\end{tabular}


Table 6. Relationship between the indicators of fecal contamination and physicochemical parameters of raw wastewater using the Pearson correlation test

\begin{tabular}{|c|c|c|c|c|c|c|c|c|c|c|}
\hline \multicolumn{2}{|c|}{} & $\mathrm{pH}$ & $\mathrm{T}^{\circ}$ & Conductivity & $\begin{array}{c}\text { Dissolved } \\
\text { Oxygen }\end{array}$ & $\mathrm{BOD} 5$ & $\mathrm{COD}$ & $\mathrm{SS}$ & $\mathrm{NO}_{3}$ & $\mathrm{PO}_{4}$ \\
\hline \multirow{2}{*}{$\mathrm{TC}$} & $\mathrm{r}$ & $-0,172$ & 0,184 & $\mathbf{0 , 6 1 2}$ & 0,232 & $-0,122$ & 0,358 & 0,380 & 0,433 & $-0,386$ \\
\cline { 2 - 12 } & $\mathrm{Sig}$ & 0,592 & 0,566 & $\mathbf{0 , 0 3 4}$ & 0,469 & 0,705 & 0,254 & 0,223 & 0,159 & 0.215 \\
\hline \multirow{2}{*}{$\mathrm{FC}$} & $\mathrm{r}$ & $-0,051$ & 0,249 & 0,549 & 0,310 & $-0,222$ & 0,318 & 0,291 & 0.476 & -0.495 \\
\cline { 2 - 12 } & $\mathrm{Sig}$ & 0,875 & 0,435 & 0,064 & 0,327 & 0,488 & 0,314 & 0,359 & 0.118 & 0.102 \\
\hline \multirow{2}{*}{$\mathrm{FS}$} & $\mathrm{r}$ & $-0,222$ &,- 066 & 0,399 & $-0,082$ & $-0,026$ & 0,301 & 0,402 & 0.128 & -0.440 \\
\cline { 2 - 12 } & $\mathrm{Sig}$ & 0,487 & 0,838 & 0,199 & 0,799 & 0,936 & 0,341 & 0,195 & 0.692 & 0.152 \\
\hline \multirow{2}{*}{ E. Coli } & $\mathrm{r}$ & 0,108 & 0,327 & 0,393 & 0,414 & $-0,267$ & 0,301 & 0,211 & -0.313 & -0.064 \\
\cline { 2 - 12 } & $\mathrm{Sig}$ & 0,738 & 0,299 & 0,207 & 0,181 & 0,402 & 0,342 & 0,511 & 0.322 & 0.843 \\
\hline
\end{tabular}

** - The correlation is significant at the 0.01 level (bilateral).

* - The correlation is significant at the 0.05 level (bilateral).

Table 7. Relationship between the indicators of fecal contamination and physicochemical parameters of treated wastewater using the Pearson correlation test

\begin{tabular}{|l|c|c|c|c|c|c|c|c|c|c|}
\hline \multicolumn{2}{|c|}{} & $\mathrm{pH}$ & $\mathrm{T}^{\circ}$ & Conductivity & $\begin{array}{c}\text { Dissolved } \\
\text { oxygen }\end{array}$ & $\mathrm{BOD} 5$ & $\mathrm{COD}$ & $\mathrm{SS}$ & $\mathrm{NO}_{3}^{-}$ & $\mathrm{PO}_{4}{ }^{3-}$ \\
\hline \multirow{2}{*}{$\mathrm{TC}$} & $\mathrm{r}$ & 0,367 & $-0,410$ & 0,033 & 0,004 & 0,050 & $-0,117$ & $-0,105$ & -0.153 & 0.533 \\
\cline { 2 - 12 } & $\mathrm{Sig}$ & 0,241 & 0,186 & 0,918 & 0,989 & 0,876 & 0,717 & 0,745 & 0.634 & 0.074 \\
\hline \multirow{2}{*}{$\mathrm{FC}$} & $\mathrm{r}$ & $-0,288$ & 0,272 & $\mathbf{0 , 6 5 9}$ & $\mathbf{0 , 7 1 2}$ & $-0,243$ & 0,406 & 0,194 & -0.218 & 0.047 \\
\cline { 2 - 11 } & $\mathrm{Sig}$ & 0,363 & 0,393 & $\mathbf{0 , 0 2 0}$ & $\mathbf{0 , 0 0 9}$ & 0,447 & 0,191 & 0,545 & 0.497 & 0.884 \\
\hline \multirow{2}{*}{$\mathrm{FS}$} & $\mathrm{r}$ & 0,246 & $-0,021$ & 0,097 & $\mathbf{0 , 7 9 7 ^ { * * }}$ & 0,113 & 0,268 & $-0,121$ & -0.375 & -0.093 \\
\cline { 2 - 11 } & $\mathrm{Sig}$ & 0,442 & 0,948 & 0,763 & $\mathbf{0 , 0 0 2}$ & 0,727 & 0,400 & 0,709 & 0.230 & 0.773 \\
\hline \multirow{2}{*}{ E. Coli } & $\mathrm{r}$ & $-0,148$ & 0,397 & $\mathbf{0 , 6 9 5}$ & $\mathbf{0 , 6 0 2}$ & $-0,240$ & 0,090 & 0,120 & -0.320 & -0.030 \\
\cline { 2 - 11 } & $\mathrm{Sig}$ & 0,646 & 0,201 & $\mathbf{0 , 0 1 2}$ & $\mathbf{0 , 0 3 8}$ & 0,452 & 0,781 & 0,709 & 0.311 & 0.925 \\
\hline
\end{tabular}

** - The correlation is significant at the 0.01 level (bilateral).

* - The correlation is significant at the 0.05 level (bilateral).

who showed a correlation between the FC and the Temperature and the $\mathrm{pH}$, it explains that the temperature and the high $\mathrm{pH}$ favor the mortality of coliforms in the waters. Other studies of seasonal variation in bacterial flora of the wastewater and soil in the vicinity of industrial area by Malik et al. (2002), recorded the effect of physicochemical parameters on the fecal coliform variability. The observed relationship between dissolved oxygen and fecal contamination indicator bacteria is directly related to the essential factors of aeration treatment where oxygen is an essential factor for treatment. The effect of physicochemical parameters on bacteria was also summarized in the study by Rosenfeld et al. (2006). He found that the load of fecal indicator bacteria is not only related to seasonal, spatial or source variability. It is also related to the fact that each type of bacteria dies at a different rate depending on environmental factors (temperature, salinity, nutrient concentration, predation, the presence or absence of bacteria, absence of bacterial toxins, solar radiation, coagulation, flocculation, and particle adsorption), all of which have an impact on the ultimate death of bacteria.

\section{CONCLUSIONS}

In Agadir, many studies have been conducted on the process of sand percolation infiltration on different aspects: physicochemical, microbiology and parasitology (Table 8). This research presents the specification to study a new system implemented in the region (activated sludge), and investigate its operation in a semi-arid climate. Monitoring of the microbiological and physicochemical parameters in all types of waters from Aourir treatment plant made it possible to assess their quality. The quality and quantity of wastewater that the Aourir plant receives depend essentially on the quantity of water consumed by the population. They also depend on the intensity of tourist activities according to the seasons. This causes fluctuations in the level of physicochemical and microbiological pollution of effluents 
Table 8. Purifying performance of wastewater treatment plants in the Agadir region.

\begin{tabular}{|c|c|c|c|c|c|c|c|c|c|c|}
\hline \multirow[b]{2}{*}{ Studies } & \multirow[b]{2}{*}{ Location } & \multirow{2}{*}{$\begin{array}{l}\text { Treatment } \\
\text { process }\end{array}$} & \multicolumn{3}{|c|}{ Treatment system } & \multicolumn{5}{|c|}{ Performance } \\
\hline & & & $\begin{array}{l}\text { Primary } \\
\text { treatment }\end{array}$ & $\begin{array}{l}\text { secondary } \\
\text { treatment }\end{array}$ & $\begin{array}{c}\text { tertiary } \\
\text { treatment }\end{array}$ & SS & BOD5 & COD & $\mathrm{FC}^{*}$ & $\mathrm{FS}^{*}$ \\
\hline $\begin{array}{l}\text { Mimouni et } \\
\text { al., (2011) }\end{array}$ & $\begin{array}{l}\text { Bensrgao } \\
\text { (Agadir, } \\
\text { Morocco) }\end{array}$ & $\begin{array}{l}\text { Infiltration- } \\
\text { percolation }\end{array}$ & $\begin{array}{c}\text { Primary } \\
\text { decanting }\end{array}$ & $\begin{array}{l}\text { Sand } \\
\text { filtration }\end{array}$ & - & $75 \%$ & $99.9 \%$ & $92.8 \%$ & 5,38 & 4,4 \\
\hline $\begin{array}{l}\text { Eddabra, } \\
\text { (2011) }\end{array}$ & $\begin{array}{l}\text { Drarga } \\
\text { (Agadir, } \\
\text { Morocco) }\end{array}$ & $\begin{array}{l}\text { Infiltration- } \\
\text { percolation }\end{array}$ & $\begin{array}{l}\text { Primary } \\
\text { decanting }\end{array}$ & $\begin{array}{l}\text { Secondary } \\
\text { treatment }\end{array}$ & - & - & - & - & 4,51 & 3,93 \\
\hline $\begin{array}{l}\text { El Heloui et } \\
\text { al., (2016) }\end{array}$ & $\begin{array}{c}\text { Tiznit } \\
\text { (Morocco) }\end{array}$ & $\begin{array}{l}\text { Natural } \\
\text { lagoon }\end{array}$ & $\begin{array}{c}\text { Anaerobic } \\
\text { basin }\end{array}$ & $\begin{array}{c}\text { Facultative } \\
\text { Basin }\end{array}$ & $\begin{array}{l}\text { Maturation } \\
\text { Basin }\end{array}$ & $71 \%$ & $88,75 \%$ & $91,39 \%$ & 4,37 & - \\
\hline $\begin{array}{l}\text { Mouhanni et } \\
\text { al., (2013) }\end{array}$ & $\begin{array}{l}\text { M'zar (Agadir, } \\
\text { Morocco) }\end{array}$ & $\begin{array}{l}\text { Infiltration- } \\
\text { percolation }\end{array}$ & $\begin{array}{c}\text { Primary } \\
\text { decanting }\end{array}$ & $\begin{array}{l}\text { Secondary } \\
\text { treatment }\end{array}$ & UV & $99.08 \%$ & $99.55 \%$ & $97.41 \%$ & 3,73 & 3,49 \\
\hline Our studies & $\begin{array}{l}\text { Aourir ( } \\
\text { Agadir, } \\
\text { Morocco) }\end{array}$ & $\begin{array}{l}\text { Activated } \\
\text { sludge }\end{array}$ & - & $\begin{array}{l}\text { Aeration } \\
\text { basin, } \\
\text { clarification }\end{array}$ & $\begin{array}{l}\text { Microfiltration, } \\
\text { UV }\end{array}$ & $98 \%$ & $96 \%$ & $91,80 \%$ & 4,9 & 4,5 \\
\hline
\end{tabular}

FC*, FS* abatement in U-log

during the year. The following conclusions were drawn from this study: All parameters were in accordance with the Moroccan standards. UV-TWs distinguished for the watering of green spaces meet the criteria set by the Moroccan and WHO reuse standards. However, UV control is necessary in order to take appropriate preventive measures to reduce the health risk and prevent further pollution of green spaces and groundwater. As a perspective, the authors are planning to study the effect of reuse of treated wastewater on irrigated green spaces.

\section{REFERENCES}

1. Abdulla, F., \& Farahat, S. 2020. Impact of Climate Change on the Performance of Wastewater Treatment Plant : Case study Central Irbid WWTP (Jordan). Procedia Manufacturing, 44, 205-212. https:// doi.org/10.1016/j.promfg.2020.02.223

2. Adouani, N., Limousy, L., Lendormi, T., \& Sire, O. 2015. N2O and NO emissions during wastewater denitrification step : Influence of temperature on the biological process. Comptes Rendus Chimie, 18(1), 15-22. https://doi.org/10.1016/j.crci.2014.11.005

3. AFNOR 1983. Recueil de normes françaises : eau, méthodes d'essai, 2e édition, Paris, 624 p.

4. Angelakis, A., Do Monte, M. M., Bontoux, L., \& Asano, T. (1999). The status of wastewater reuse practice in the Mediterranean basin: Need for guidelines. Water research, 33(10), 2201-2217.

5. Arcand, Y., Paris, J., Rouleau, D., \& Mayer, R. 2005. Effets de paramètres d'opération sur la décantation de boues biologiques d'une unité de traitement d'eaux usées de raffinerie. Revue des sciences de l'eau, 2(1), 43-69. https://doi.org/10.7202/705023ar
6. Baharvand, S., \& Daneshvar, M.R.M. 2019. Impact assessment of treating wastewater on the physiochemical variables of environment : A case of Kermanshah wastewater treatment plant in Iran. Environmental Systems Research, 8(1), 1-11. https://doi. org/10.1186/s40068-019-0146-0

7. Bali, M., Gueddari, M., \& Boukchina, R. 2010. Treatment of secondary wastewater effluents by infiltration percolation. Desalination, 258 (1-3), 1-4. https://doi.org/10.1016/j.desal.2010.03.041

8. Benyakhlef, M., Naji, S., \& Belghyti, D. 2007. Caractérisation des rejets liquides d'une conserverie de poissons. Bull. Soc. Pharm. Bordeaux, 146, 225-234.

9. Boehm, A.B., \& Sassoubre, L. M. 2014. Enterococci as indicators of environmental fecal contamination. Enterococci: from commensals to leading causes of drug resistant infection. Massachusetts Eye and Ear Infirmary, pp. 1-31.

10. Bouknana, D., Hammouti, B., Salghi, R., Jodeh, S., Zarrouk, A., Warad, I., Aouniti, A., \& Sbaa, M. 2014. Physicochemical characterization of olive oil mill wastewaters in the eastern region of Morocco. J. Mater. Environ. Sci, 5(4), 1039-1058. http:// dx.doi.org/10.22159/jcr.2018v5i5.28840

11. Bourouache, M., Mimouni, R., Ait Alla, A., Hamadi, F., El Boulani, A., \& Bihadassen, B. 2019. Bacteriological and physicochemical quality of treated wastewater of the Mzar treatment plant. Applied Water Science, 9(4), 86. http://dx.doi.org/10.1007/ s13201-019-0958-0

12. Boutayeb, M., Bouzidi, A., \& Fekhaoui, M. 2012. Etude de la qualité physico-chimique des eaux usées brutes de cinq villes de la région de la ChaouiaOuardigha (Maroc). Bulletin de l'Institut Scientifique, 145-150.

13. Cha, W., Choi, H., Kim, J., \& Kim, I. S. 2004. Evaluation of wastewater effluents for soil aquifer 
treatment in South Korea. Water Science and Technology, 50(2), 315-322. https://doi.org/10.2166/ wst.2004.0147

14. Chapman, D.V. 1996. Water quality assessments : A guide to the use of biota, sediments and water in environmental monitoring. CRC Press.

15. Collivignarelli, M.C., Abbà, A., Benigna, I., Sorlini, S., \& Torretta, V. 2018. Overview of the main disinfection processes for wastewater and drinking water treatment plants. Sustainability, 10(1), 86. https:// doi.org/10.3390/su10010086

16. Deronzier, G., Schétrite, S., Racault, Y., Canler, J.P., Liénard, A., Héduit, A., \& Duchène, P. 2002. Traitement de l'azote dans les stations d'épuration biologique des petites collectivités. Cemagref Editions, pp.78. Documentation technique FNDAE, $\mathrm{n}^{\circ}$ 25, 2-85362-555-9. ffhal-02580469.

17. Bachi, E.O., Halilat, T.M., Bissati, S. \& Mehanna, F.S. 2020. Performance of two free biomass biological wastewater treatment processes (Aerated Lagoon and Activated Sludge) in Ouargla area, Algeria with referring to re-use the treated water in aquaculture. Egyptian Journal of Aquatic Biology and Fisheries, 24(7-Special issue), 575-592. https:// doi.org 10.21608/EJABF.2020.123156

18. Eddabra R. 2011. Evaluation de la Contamination bactériologique des eaux usées des stations d'épuration du grand Agadir : isolement, caractérisation moléculaire et antibio-résistance des espèces du genre Vibrio. Thèse de doctorat, Ibn Zohr, Strasbourg, pp.146.

19. El Haouti, R., Et-Taleb, S., Abbaz, M., Lhanafi, S., Azougarh, Y., Ez-Zahery, M., Aba-Aaki, R., \& El Alem, N. 2015. The use of titaniferous sieved sand for the treatment of domestic wastewater in the percolation infiltration process. Arab J Chem Environ Sci, 2(2), 58-71.

20. Et-Taleb, S., Elhaouti, R., Abbaz, M., Lhanafi, S., Ez-Zahery, M., Aba-Aaki, R., \& El Alem, N. 2014. Comparaison du phénomène de colmatage des eaux usées à travers deux types de sables : L'un vierge et l'autre utilisé lors de traitement par infiltration (Comparison of the clogging phenomenon wastewater through two types of sand: One virgin and one used during treatment with infiltration). J. Mater. Environ. Sci, 5(6), 1906-1912.

21. Fatta-Kassinos, D., Kalavrouziotis, I. K., Koukoulakis, P.H., \& Vasquez, M. 2011. The risks associated with wastewater reuse and xenobiotics in the agroecological environment. Science of the Total Environment, 409(19), 3555-3563. https://doi. org/10.1016/j.scitotenv.2010.03.036

22. Finch, G.R., \& Smith, D.W. 1986. Batch coagulation of a lagoon for fecal coliform reductions. Water Research, 20(1), 105-112. https://doi.org/10.1016/0 043-1354(86)90221-6
23. Fonteneau, L., Da Silva, N.J., Fabre, L., Ashton, P., Torpdahl, M., Müller, L., Bouchrif, B., El Boulani, A., Valkanou, E., \& Mattheus, W. 2017. Multinational outbreak of travel-related Salmonella Chester infections in Europe, summers 2014 and 2015. Eurosurveillance, 22(7), 30463.

24. Geldreich, E.E. 1966. Sanitary significance of fecal coliforms in the environment. US Department of the Interior, Federal Water Pollution Control Administration.

25. Habbari, K., Tifnouti, A., Bitton, G., \& Mandil, A. 2000. Geohelminthic infections associated with raw wastewater reuse for agricultural purposes in Beni-Mellal, Morocco. Parasitology international, 48(3), 249-254. https://doi.org/10.1016/ S1383-5769(99)00026-4

26. Hachemi, O.E., Halouani, H.E., Meziane, M., Torrens, A., \& Sbaa, M. 2012. Etude des performances épuratrices dans une station de traitement des eaux usées par lagunage en climat désertique (Oasis de Figuig-Maroc): Aspect bactérien et organique. Rev. Microbiol. Ind. San et Environn, 6(1), 84-97.

27. Haité, H.E. 2010. Traitement des eaux usées par les réservoirs opérationnels et réutilisation pour l'irrigation, Engineering Sciences. Ecole Nationale Superieure des Mines de Saint-Etienne, 2010. French. $<$ NNT : 2010EMSE0569>. 205.

28. Hamoda, M., Al-Ghusain, I., \& Al-Mutairi, N. 2004. Sand filtration of wastewater for tertiary treatment and water reuse. Desalination, 164(3), 203-211. https://doi.org/10.1016/S0011-9164(04)00189-4

29. Hassoune, E.M., Bouzidi, A., Koulali, Y., \& Hadarbach, D. 2006. Effets des rejets liquides domestiques et industriels sur la qualité des eaux souterraines au nord de la ville de Settat (Maroc). Bulletin de 1'Institut Scientifique, Rabat, section Sciences de la Vie, 28, 61-71, 11.

30. ISO 9308-1. 2000. Water quality-Detection and enumeration of Escherichia coli and coliform bacteria - Part 1: Membrane filtration method.

31. Joel, C., Mwamburi, L.A., \& Kiprop, E.K. 2018. Use of slow sand filtration technique to improve wastewater effluent for crop irrigation. Microbiology Research, 9(1), 14-18.

32. Köck-Schulmeyer, M., Villagrasa, M., deAlda, M.L., Céspedes-Sánchez, R., Ventura, F., \& Barceló, D. 2013. Occurrence and behavior of pesticides in wastewater treatment plants and their environmental impact. Science of the total environment, 458, 466-476. https://doi.org/10.1016/j.scitotenv.2013.04.010

33. Lazarova, V., Janex, M., Fiksdal, L., Oberg, C., Barcina, I., \& Pommepuy, M. 1998. Advanced wastewater disinfection technologies : Short and long term efficiency. Water Science and Technology, 38(12), 109-117. https://doi.org/10.1016/ S0273-1223(98)00810-5 
34. Maiga, A., Konate, Y., Wethe, J., Denyigba, K., Zoungrana, D., \& Togola, L. 2006. Performances épuratoires d'une filière de trois étages de bassins de lagunage à microphytes sous climat sahélien : Cas de la station de traitement des eaux usées de l'EIER. Sud sciences \& technologies, 14, 1-9.

35. Makhoukh, M., Sbaa, M., \& Berrahou, A. 2011. Contribution à l'étude physico-chimique des eaux superficielles de l'oued Moulouya (Maroc Oriental). Larhyss Journal, 9, 21.

36. Malik, A., \& Ahmad, M. 2002. Seasonal variation in bacterial flora of the wastewater and soil in the vicinity of industrial area. Environmental monitoring and assessment, 73(3), 263-273.

37. Mandi, L., \& Ouazzani, N. 2013. Water and wastewater management in Morocco: Biotechnologies application. Sustainable Sanitation Practice, 1(14), 9-16.

38. Merghem, K.A., El, H., Mokhtari, O., Alnedhary, A.A., Belkhir, H., Dssouli, K., Ait, N., Elkhadir, G., \& Chetouani, A. 2016. Quality assessment and potential reuse of treated wastewater by activated sludge (Sana'a city, Yemen). Moroccan Journal of Chemistry, 4(3), 731-742.

39. Mezrioui, N., \& Baleux, B. 1994. Resistance patterns of E. coli strains isolated from domestic sewage before and after treatment in both aerobic lagoon and activated sludge. Water Research, 28(11), 2399-2406.

40. Bulletin officiel. 2002. Ministère de l'environnement du Maroc. 2002. Normes marocaines, Bulletin officiel du Maroc, $\mathrm{N}^{\circ} 5062$ du 30 ramadan 1423. Rabat.

41. Mimouni, R., Yacoubi, B., \& Eddabra, R. 2011. Physicochemical quality of wastewater purified by infiltration-percolation : Case of the plant of Ben Sergao (south-western Morocco) after ten years of running. Rev. Microbiol. Ind. San et Environn, 5(1), 101-114.

42. Mouhanni, H., Bendou, A., \& Houari, M. 2013. Study of the Wastewater Purifying Performance in the M'Zar Plant of Agadir, Morocco. Environment and Pollution, 2(3), p20. https://doi.org/10.5539/ ep.v2n3p20

43. Omura, T., Onuma, M., Aizawa, J., Umita, T., \& Yagi, T. 1989. Removal Efficiencies of Indicator Micro-Organisms in Sewage Treatment Plants. Water Science and Technology, 21(3), 119-124. https:// doi.org/10.2166/wst.1989.0088

44. Pearson, H., Mara, D., Mills, S., \& Smallman, D. 1987. Physico-chemical parameters influencing faecal bacterial survival in waste stabilization ponds. Water science and technology, 19(12), 145-152.

45. Petala, M., Tsiridis, V., Samaras, P., Zouboulis, A., \& Sakellaropoulos, G. 2006. Wastewater reclamation by advanced treatment of secondary effluents. Desalination, 195(1-3), 109-118.
46. Qadir, M., Wichelns, D., Raschid-Sally, L., McCornick, P.G., Drechsel, P., Bahri, A., \& Minhas, P. 2010. The challenges of wastewater irrigation in developing countries. Agricultural water management, 97(4), 561-568. https://doi.org/10.1016/j. agwat.2008.11.004

47. Quevedo, N., Sanz, J., Lobo, A., Temprano, J., \& Tejero, I. 2012. Filtration demonstration plant as reverse osmosis pretreatment in an industrial water treatment plant. Desalination, 286, 49-55. https:// doi.org/10.1016/j.desal.2011.10.037

48. Raji, M., Ibrahim, Y., Tytler, B., \& Ehinmidu, J. 2015. Faecal Coliforms (FC) and Faecal Streptococci (FS) ratio as tool for assessment of water contamination : A case study of River Sokoto, Northwestern Nigeria. The Asia Journal of Applied Microbiology, 2(3), 27-34.

49. Rodier, J., Legube, B., \& Merlet, N. 1959. L'analyse de l'eau-9e éd.: Eaux naturelles, eaux résiduaires, eau de mer (Water Analysis-9th ed: Natural Waters, Waste Waters, Seawater 2009). Dunod

50. Rosenfeld, L., McGee, C., Robertson, G., Noble, M., \& Jones, B. 2006. Temporal and spatial variability of fecal indicator bacteria in the surf zone off Huntington Beach, CA. Marine environmental research, 61(5), 471-493. https://doi.org/10.1016/j. marenvres.2006.02.003

51. Shahalam, A. 1989. Wastewater effluent vs. Safety in its reuse: State-of-the-art. The Journal of Environmental Sciences, 32(5), 35-42. https://doi. org/10.17764/jiet.1.32.5.emq35781761 m2658

52. Sharrer, M.J., Summerfelt, S.T., Bullock, G.L., Gleason, L.E., \& Taeuber, J. 2005. Inactivation of bacteria using ultraviolet irradiation in a recirculating salmonid culture system. Aquacultural Engineering, 33(2), 135-149. https://doi.org/10.1016/j. aquaeng.2004.12.001

53. Tahri, M., Larif, M., Quabli, H., Taky, M., Elamrani, M., El Midaoui, A., Benazouz, K., \& Khimani, M. 2015. Etude et suivi des performances des traitements primaire et secondaire des eaux usées de la station d'épuration de Marrakech. European Scientific Journal, J 11(17), 139-154.

54. Tarchouna, L.G., Merdy, P., Raynaud, M., Pfeifer, H.-R., \& Lucas, Y. 2010. Effects of long-term irrigation with treated wastewater. Part I: Evolution of soil physico-chemical properties. Applied Geochemistry, 25(11), 1703-1710. https://doi.org/10.1016/j. apgeochem.2010.08.018

55. Vaz-Moreira, I., Nunes, O.C., \& Manaia, C.M. 2014. Bacterial diversity and antibiotic resistance in water habitats : Searching the links with the human microbiome. FEMS microbiology reviews, 38(4), 761-778. https://doi.org/10.1111/1574-6976.12062 